\title{
LOCALITY MAPS
}

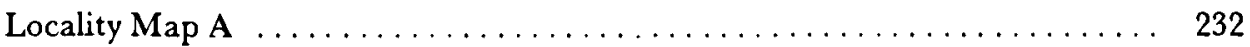

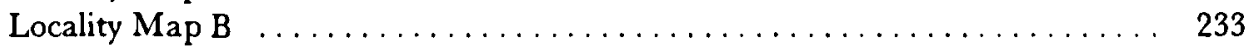

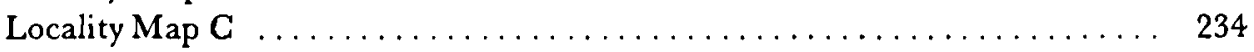

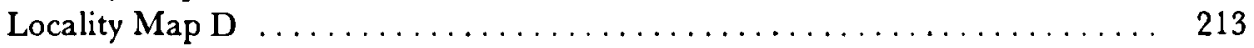





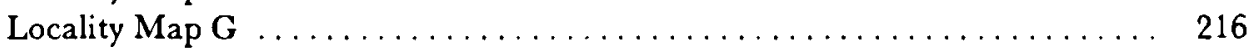

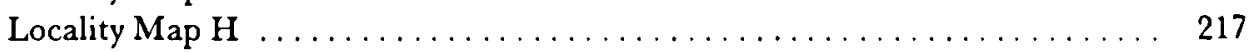

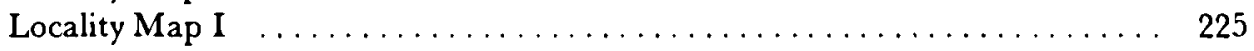

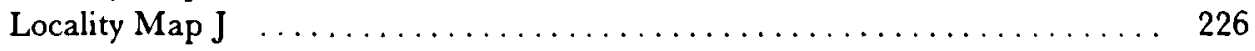

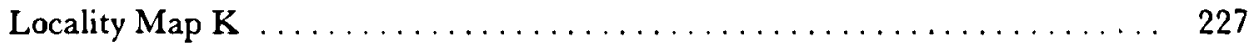

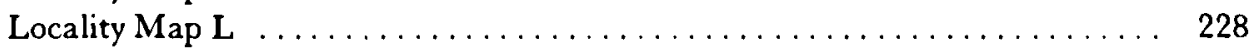

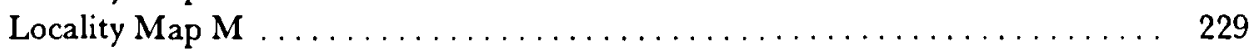

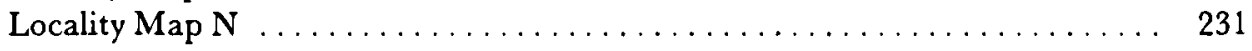

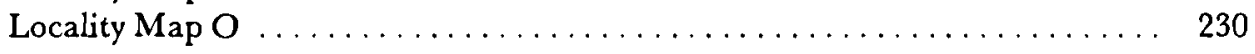

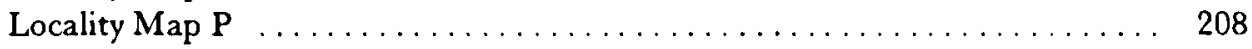

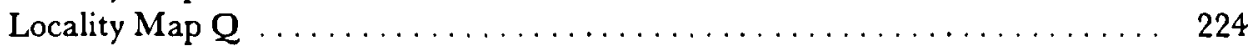

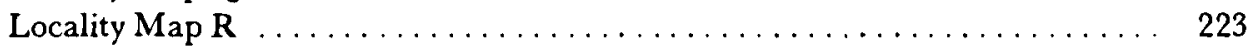

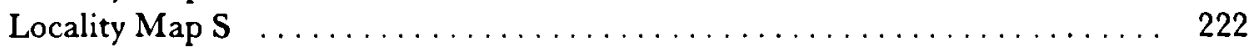





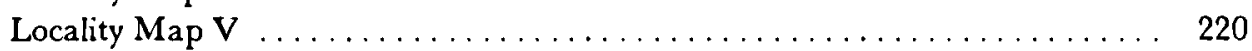

Locality Map W . . . . . . . . . . . . . . . . . . . . . . . . . 219

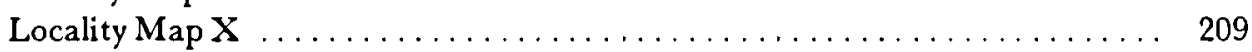


This page intentionally left blank 